\title{
OCCUPATIONAL FATIGUE BASED ON WORK SHIFT AMONG MEDICAL WORKERS AT DR HARJONO HOSPITAL
}

\author{
Dian Afif Arifah, Yulia Dwi Andarini, Rindang Dianita \\ Prodi D4 Keselamatan dan Kesehatan Kerja Fakultas Ilmu Kesehatan Universitas Darussalam Gontor
}

\begin{abstract}
Working on daytim, is normal activity according to human physiological conditions, but working on the night would impact the sleep cycle and regulation of human homeostasis. Various studies have found that working at night causing conditions that can interfere with the ability to adapt both biologically and socially. Workers on the night shift also have a higher risk of injury or accidents due to work fatigue. This study aimed to further examine the potential pathways in shift work that may lead to the risk of occupational fatigue among medical workers. This study was an observational study with a cross-sectional design. Data Collected in August 2019 and involved 80 medical workers as respondents who were randomly selected using simple random sampling technique. Data were obtained through direct observation and interviews with respondents. Fatigue was measured in numerical score with Fatigue Assesment Scale (FAS) Instrument. Work shift variables (WS) are divided into non-night shifts (morning, noon) and night shift (morning, noon, night). To find out the differences in physical conditions of workers in each shift, the Heart Rate (HR) of the night shift workers measured at the end of three shifts (morning 07-14.00; Afternoon 14.00-21.00; and night 21.00-07.00). The unpaired T-test with a 95\% confidence level was used to analyze differences in the level of fatigue in night shift workers and non-night shift workers. Dependent T-test with a 95\% confidence Interval used to analyze differences in the level of fatigue among night shift workers and nonnight shift workers. The data analysis result shows that there was a significant difference in fatigue levels of workers with night shifts and non-night shifts $(p<0.000)$. Workers with the night shift have 29.0 of Fatigue Levels or $21 \%$ greater than workers with non-nigh shift (fatigue levels 24.2). Result shows that working at night increasing level of fatigue by $21 \%$ than working at day. Workers on the night shift have the highest HR at the end of the shift (86.311 bpm).
\end{abstract}

Keywords: Occupational fatigue, work shift, medical worker

\section{KELELAHAN KERJA BERDASARKAN SHIFT KERJA PADA PEKERJA MEDIS DI RUMAH SAKIT DR HARJONO}

\begin{abstract}
Bekerja pada siang hari, adalah aktivitas normal menurut kondisi fisiologis manusia, namun bekerja pada malam hari akan berdampak pada siklus tidur dan regulasi homeostasis manusia. Berbagai penelitian telah menemukan bahwa bekerja di malam hari menyebabkan kondisi yang dapat mengganggu kemampuan beradaptasi baik secara biologis maupun sosial. Pekerja pada shift malam juga memiliki risiko cedera atau kecelakaan yang lebih tinggi akibat kelelahan kerja. Penelitian ini bertujuan untuk menguji apakah shift malam dapat menyebabkan risiko kelelahan kerja pada pekerja medis Rumah Sakit Dr Harjono S, Ponorogo. Penelitian ini merupakan penelitian observasional dengan desain cross-sectional. Data melibatkan 80 pekerja medis sebagai responden yang dipilih secara acak menggunakan teknik simple random sampling. Data diperoleh melalui observasi langsung dan wawancara kepada responden. Kelelahan diukur dalam skor numerik dengan Instrumen Skala Kelelahan (FAS). Variabel shift kerja dibagi menjadi: non-sift malam (pagi, siang) dan shift malam (pagi, siang, malam). Untuk mengetahui perbedaan kondisi fisik pekerja di setiap shift, denyut nadi pekerja shift malam diukur pada akhir tiga shift (pagi: 07-14.00; Sore: 14.00-21.00; dan malam: 21.00- 07.00). Uji T tidak berpasangan dengan derajat kepercayaan 95\% digunakan untuk menganalisis perbedaan level fatigue pada pekerja shift malam dan non-shift malam. Hasil analisis data menunjukkan bahwa terdapat perbedaan yang signifikan pada tingkat kelelahan pekerja dengan shift malam dan pekerja tanpa shift malam $(\mathrm{p}<0,000)$. Pekerja dengan shift malam memiliki rata-rata tingkat
\end{abstract}

Correspondece Address: Dian Afif Arifah Fakultas Ilmu Kesehatan Universitas Darussalam Gontor Email: dianafif@ unida.gontor.ac.id 
kelelahan sebesar 29.0 atau $21 \%$ lebih besar daripada pekerja tanpa shift malam (Tingkat Kelelahan: 24.2). Hasil penelitian menunjukkan bahwa bekerja di malam hari meningkatkan tingkat kelelahan sebesar $21 \%$ dibandingkan bekerja di siang hari. Pekerja pada shift malam memiliki HR tertinggi pada akhir shift (86.311 bpm).

Kata Kunci : Kelelahan kerja, shift, tenaga medis

\section{INTRODUCTION}

In the industrial era, approximately $20 \%$ of the total worker engages in some type of shift work schedule. ${ }^{1}$ Some company has to implement 24 operation hour system to sustain the demand for product or services such as the hospital. Based on data from the National Labor Force Survey (SAKERNAS) 2017, the percentage of workers in the health and social sector is about 1.97 million of the total working people in Indonesia. ${ }^{2}$ Most health service providers such as hospitals, require the implementation of a rotating work (Work Shift) system.

Working on daytime is normal activity according to human physiological conditions, but working on the night would impact the sleep cycle and regulation of human homeostasis. ${ }^{3}$ The various studies found that shift work has been associated with assorted maladies, including sleep disruption, fatigue, cognitive impairment, accidents, injuries, depression, metabolic and gastrointestinal disturbances, and increased risks for diabetes, cardiovascular disease, and cancer. ${ }^{4-9}$

The relations between working conditions and various aspects of health among hospital workers once studied in the Nigerian Hospital. The main cause of sick leave was musculoskeletal disorders and affected $16 \%$ of the workers for the 12-month study. Back pain was described by $75.3 \%$ of the nurses as the manifestation of occupational fatigue. ${ }^{10}$ Three working activities that considered to characterize the work fatigue are standing more than six hours a day, bending over more than ten times per hour, and maintaining an uncomfortable posture. This study aimed to examine further the potential pathways in shift work that may lead to the risk of occupational fatigue among medical workers.

In Poland, $32.8 \%$ of the total violent workplace accidents suffered from occupational fatigue. Fatigue can be caused by physical or mental stress. It has negative effects on subjective and physiological sleepiness, performance, accident risk, cardiovascular disease, and certain forms of cancer. ${ }^{11}$

Data from Poland National Roads below describe how the relationships between the concentration of accidents and casualties and the clock time of day.

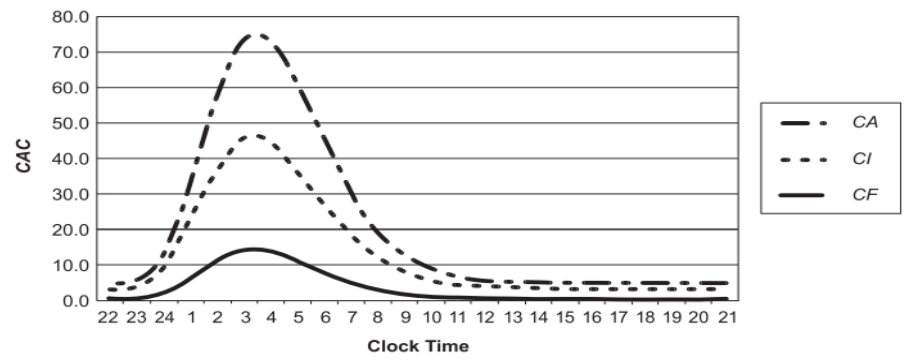

$\mathrm{CA}:$ concentration of road
accidents
$\mathrm{Cl}:$ concentration of injuries
$\mathrm{CF}:$ concentration of fatalities

Figure 1. Distribution of the average concentration of fatigue-related accidents and casualties on Poland's national roads 
As can be seen from the chart in figure 1 that the concentration of fatigue-related accidents and casualties on Poland's national roads is highest from 2 to 6 am. ${ }^{12}$ Some studies try to explain the aspects of shift and work time. working at night causing conditions that can interfere with the ability to adapt both biologically and socially. Immediate disturbances associated with shift work are symptoms such as sleep disturbances, fatigue, 'jet lag' and gastrointestinal. ${ }^{13}$ The long term night shift work has been associated with an increased risk of obesity, ${ }^{14}$ breast cancer, ${ }^{15}$ cardiovascular disease (CVD), ${ }^{16}$ gastrointestinal disorders, ${ }^{17}$ and possibly elevated mortality risk. Normally, the average heart rate increases in the morning after awakening reaches a peak between 10 to 12 o'clock, then gradually declines later and maintaining a low level during the night. ${ }^{18}$

Based on the background explained in this section, this study aims to determine the Occupational fatigue level based on shift difference among medical workers, Dr. RSUD. Hardjono S. Ponorogo.

\section{METHOD}

This research located at Dr. Hardjono S. Hospitals Ponorogo, which is the only public Hospitals managed by local government and operates 24 hours a day. In this research, workers divided into night shift workers who work in three $^{3}$ working time (morning, afternoon and night) and non-night shift workers who work in the daytime only.

Using observational method and crosssectional design, data collected in August 2019. Three hundred and sixty-three (636) workers became the population in this study. Using the cross-sectional sample size formula of Lemeshow, ${ }^{19}$ the minimum sample size needed is 62 respondents. In this study, 80 medical workers choose to participate as respondents to avoid data missing in the data collection process. They were chosen randomly using simple random sampling. Data obtained through direct observation and interviews with respondents through the procedure as described in the following figure.

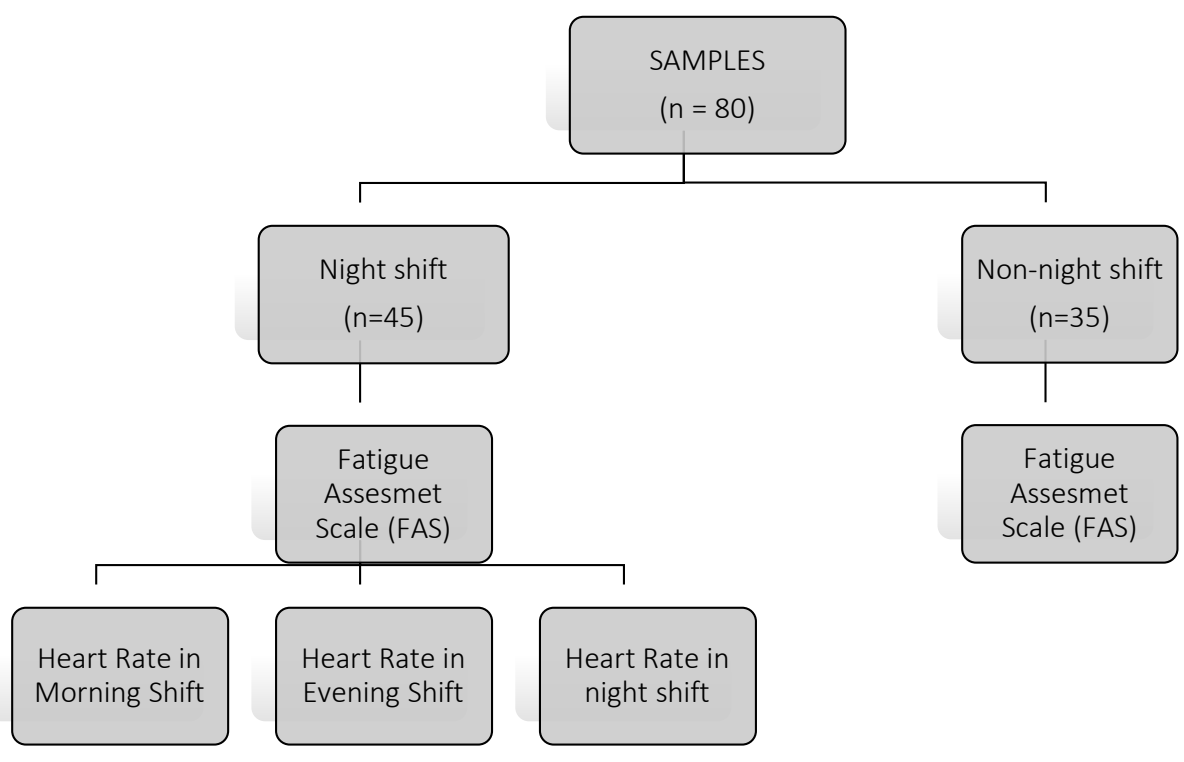

Figure 2. Pathway of Data Collection 
The independent variable is work shift (WS) which is categorized into the night and non-night shifts. The dependent variable is Occupational Fatigue wich measured on a numerical scale with Fatigue Assesment Scale (FAS) (20) Instrument and Heart Rate (HR) measured at the end of shift to find out physical conditions among medical workers in each shift.

Data analyzed using the independent t-test to determine the difference of Fatigue Scale in the night and non-night shift and one-way ANOVA to determine the difference of Heart Rate within three shifts (morning, evening and night shift)

\section{RESULTS}

This following figure describe the difference of fatigue symptom score between night shift and non-night shift workers.

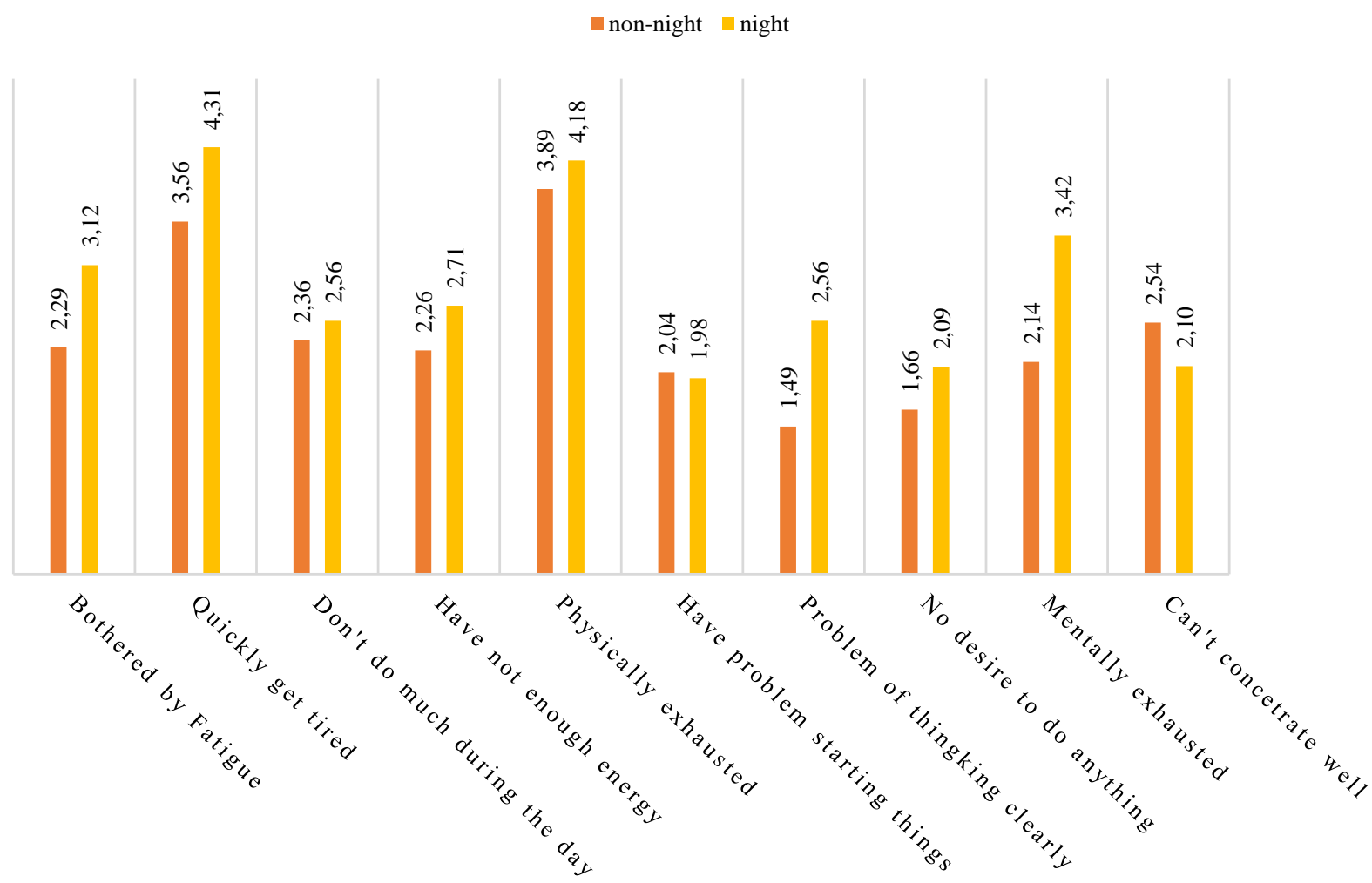

Figure 3. The average score of fatigue symptoms of night and non-night shift workers

Based on figure 3, symptoms most experienced by workers are "get tired quickly" and "physically exhausted".

The total scores of FAS can range from 10, indicating the lowest level of fatigue, to 50, denoting the highest. The following figure shows the result of total fatigue assessment scores among night shifts and non-night shifts workers. 


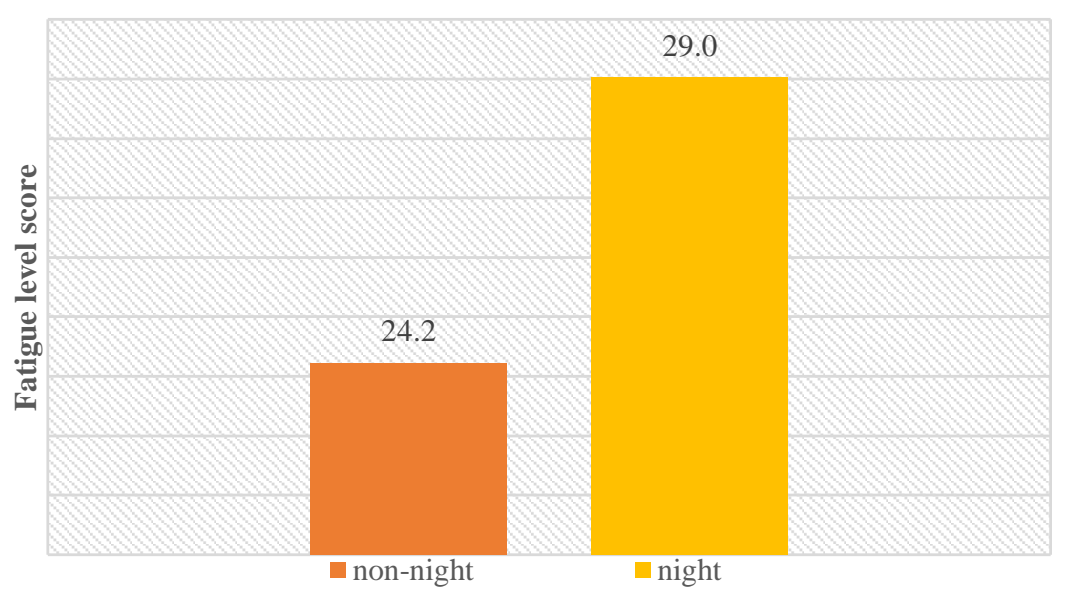

Figure 4. Average Fatigue Assessment Score of night and non-night shift

Based on figure 4, the night shift workers have an average Fatigue score of 2.90 or $21 \%$ greater compared to the non-night shift workers (2.42).

Using independent $\mathrm{t}$-test with $95 \%$ Confidence Interval known that there is a significant difference in fatigue levels among night and non-night shift workers (pvalue $=0.00$ ).
To find out the differences in physical conditions of workers in each shift, the Heart Rate (HR) of the night shift workers measured in the end of three shifts (morning 07-14.00; Afternoon 14.00-21.00; and night 21.00-07.00). The result of the analysis showed by the following figure

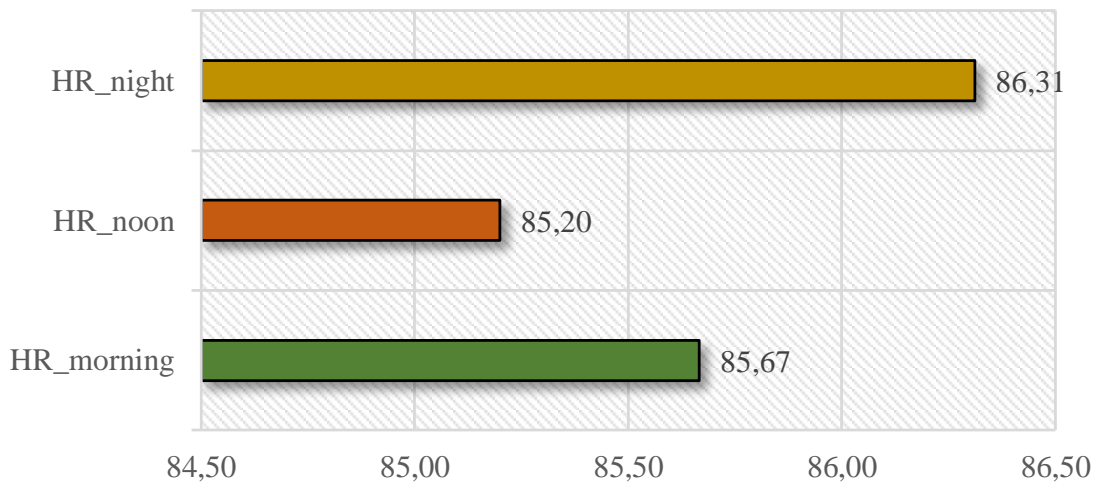

Figure 5. Heart Rate at the end of shifts

Figure 5 shows that workers on the night shift have the highest $\mathrm{HR}$ at the end of the shift $(86.311 \mathrm{bpm})$ while workers at noon shift have the lowest HR (85.2). However, the anova test did not show a significant difference of HR among those three shifts ( $\mathrm{p}$-value $=0.26)$. This result indicates that there is no difference in physical condition among workers in the morning, afternoon, and night shift. 


\section{DISCUSSION}

Shift work is strongly associated with FAS Score among this group of medical workers. Our result is similar to results in one study about High fatigue and its associations with health and workrelated factors among female medical personnel at 54 hospitals in Zhuhai, China. ${ }^{21}$ It revealed that approximately $83 \%$ of participants had experienced fatigue in the past week. The risk of fatigue was higher in aged 30-39 years old, those who have less sleeping time, and the bad tense physician-patient relationship. Depression and anxiety were found most related to fatigue.

Compared to non-shift workers, shift workers have a poorer quality of sleep, less likely to feel refreshed in the morning, and often complain of fatigue. The working activity was considered to characterize the occupational fatigue among medical shift worker are standing more than six hours, bending over more than ten times per hour, maintaining an uncomfortable posture, and waking up all night in the night shift hour. These conditions are not experienced by non-night shift workers such as administrators, officers, janitors, laundry workers, and more.

Additionally, fatigue was associated with occupation, marital status, lifestyle factors (exercise, regular diet, and health status), and work-related factors such as workload and turnover intention. ${ }^{21}$ We systematically investigated whether the age, marital status, and work periode contributed as mediators in the relationship between shift work and the Occupational Fatigue, and we found no such evidence.

Sleep quality is one of the variable that directly affected by the rotating work system and related to the work fatigue. ${ }^{7}$ Several studies on shift work scope has found that those who work in the night shift are more likely to complain of sleepiness. ${ }^{4,11,22,23}$ The American Academy of Sleep Medicine revealed that the night shift is causing sleep disorder and indirectly correlated to fatigue through circadian misalignment. ${ }^{13}$

From a methodological perspective, the measures of occupational fatigue in our study could have lacked precision. Our measurements did not allow us to identify when in the shift hour a respondent had the highest fatigue level and did the fatigue level decrease in the day shift. In addition, we did Heart Rate measurement to identify when in the shift hour, a respondent had the highest fatigue level. As the result described before, there is no significant difference in heart rate among three shift.

The question is what should we do to minimize the negative effect of the night shift or lowering the level of fatigue caused by the implementation of the night shift.

Jensen $^{24}$ did a shift intervention to the night shift workers. They divided into 2, 4 and 8 consecutive night shifts and recovery days to see how the concentration of melatonin and cortisol hormones production change. There was a significant difference between the interventions in the rhythm of melatonin on the days with night shifts. The concentration of melatonin was highest on the $2+2$ intervention.

In summary, results showed that the diurnal rhythms of melatonin and cortisol all changed differently to an increasing number of consecutive night shifts.

As described before in this section, good sleep quality also contributes to minimizing the bad effect of night shift among shift workers. Based on Safitra ${ }^{25}$ There was a significant relationship between hygiene behavior and sleep quality. Sleep hygiene behaviors such as brushing teeth, washing feet, and face considered to influence sleep quality. We sugges to night shift workers to implementing sleep hygiene to improving sleep quality. 


\section{CONCLUSION}

The result shows that there was a significant difference in Fatigue level among medical workers between night shift workers and non-night shift workers $(\mathrm{p}<0.000)$. Workers with the night shift have 29.0 of fatigue level or $21 \%$ greater than workers with non-nigh shift (Fatigue Level: 24.2). The heart rate (HR)

\section{REFERENCE}

1. Lajoie P, Aronson KJ, Day A, Tranmer J. A cross-sectional study of shift work, sleep quality and cardiometabolic risk in female hospital employees. BMJ journalournal. 2015;5(3):1-8.

2. SAKERNAS. Keadaan Angkatan Kerja Indonesia February 2019. 2017. Available from: https://www.bps.go.id/publication/downl oad.

3. Shu Hui Lin RN, MS., Wen Chun Liao RN, PhD., Mei Yen Chen RN, PhD., Jun Yu Fan RN P. The impact of shift work on nurses' job stress, sleep quality and self-perceived health status. J Nurshing Manag. 2012;22(5):604-12.

4. Reutrakul S, Knutson KL. Consequences of Circadian Disruption on Cardiometabolic Health. Sleep Med Clin. 2016;10(4):455-68.

5. Videnovic A, Hospital MG, Zee PC. Consequences of Circadian Disruption on Neurologic Health. Sleep Med Clin. 2016;10(4):469-80.

6. IARC. Painting, firefighting, and shiftwork. IARC monographs on the evaluation of carcinogenic risks to humans. Lyon; 2010.

7. Faraut $\mathrm{B}$, Descartes $\mathrm{P}$, Leger D. Neuroendocrine, immune and oxidative stress in shift workers. Sleep Med Rev. 2013;17(January 2018):433-44.

8. Folkard S, Lombardi DA, Tucker PT. Shiftwork: Safety, Sleepiness and Sleep. Ind Health. 2005;43:20-3. measurement indicates that workers who work in the night shift have the highest HR in the end of the shift $(86.311 \mathrm{bpm})$. We suggest based on the discussion, that the implementation of the night shift is no more than two days in a row then followed by at least two recovery days.

9. Claire C. Caruso, PhD R. HHS Public Access. Rehabil Nurs. 2015;39(1):16-25.

10. Sikiru L, Hanifa S. Prevalence and risk factors of low back pain among nurses in a typical Nigerian hospital. African Heal Sci. 2010;10(1).

11. Torbjörn Åkerstedt, PhD., Kenneth P. Wright Jr. P. Sleep Loss and Fatigue in Shift Work and Shift Work Disorder. Sleep Med Clin. 2010;4(2):257-71.

12. Jamroz K. Driver Fatigue and Road Safety on Poland' s National Roads. Int J Occup Saf Ergon. 2013;19(May 2014):297-309.

13. Knutsson A. In-Depth Review: Shift Work. Occup Med (Chic Ill). 2003;(53):103-8.

14. Brigitte M.Kudielka, Jörg Buchtal, Alexander Uhde SW. Circadian cortisol profiles and psychological self-reports in shift workers with and without recent change in the shift rotation system. Biol Psychol. 2007;74(1):92-103.

15. Lamond N, Dorrian J, Burgess H, Holmes A, Roach G, McCulloch K, Fletcher A DD. Adaptation of performance during a week of simulated night work. Ergonomics. 2004;47(2):154-65.

16. Lowden A. Suppression of sleepiness and melatonin by bright light exposure during breaks in night work. J Sleep Res. 2004;13(1):37-43.

17. Rafael Luboshitzky, Zila Shen-Orr Ph. Middle-Aged Men Secrete Less Testosterone at Night Than Young 
Healthy Men. J Clin Endocrinol Metab. 2003;88(7):3160-6.

18. Norihiko Takeda KM. Circadian clock and the onset of cardiovascular events. Hypertens Res. 2016;39(6):383-390.

19. Lemeshow S, Jr DWH, Klar J, Lwanga SK. Stanley Lemeshow, David W Hosmer Jr, Janelle Klar, and Stephen K. Lwanga. World Health Organization; 1990.

20. Carole B, Msn S, Gnp ANP. The Pittsburgh Sleep Quality Index ( PSQI ) The Pittsburgh Sleep Quality Index ( PSQI ). Vol. 29. New York; 2012. p. 1-2.

21. Shu Cai, Hong Lin, Xuan Hu, Yue-Xiu Cai, Ken Chen W-ZC. High fatigue and its associations with health and work related factors among female medical personnel at 54 hospitals in Zhuhai, China. Psychol Health Med.
2018;23(3):304-16.

22. Coggins R Smith, MR Rosekind, S Hurd KB. Relationship of day versus night sleep to physician performance and mood. Ann Emerg Med. 1994;24(34).

23. Mayumi Arimura, Makoto IMAI MO. Sleep, Mental Health Status, and Medical Errors among Hospital Nurses in Japan. Ind Health. 2010;48:811-7.

24. Jensen MA. Working in the "Middle of the Night." University of Copenhagen; 2015.

25. Safitra AR, Muharyani PW. Relationship Between Sleep Hygiene And Sleep Quality In Adolescents Aged 12-15 Years, Study Design and Sampling Procedure. J Ilmu Kesehat Masy. 2019;10(March):59-66. 